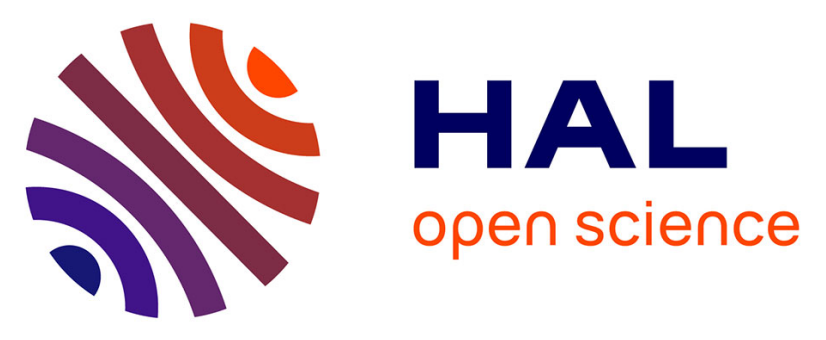

\title{
Dark fermentative hydrogen production by anaerobic sludge growing on glucose and ammonium resulting from nitrate electroreduction
}

Rawa Abdallah, Hayet Djelal, Abdeltif Amrane, Walaa Sayed, Florence

Fourcade, Thierry Labasque, Samir Taha, Florence Geneste, Didier Floner

\section{To cite this version:}

Rawa Abdallah, Hayet Djelal, Abdeltif Amrane, Walaa Sayed, Florence Fourcade, et al.. Dark fermentative hydrogen production by anaerobic sludge growing on glucose and ammonium resulting from nitrate electroreduction. International Journal of Hydrogen Energy, 2016, 41 (12), pp.5445-5455. 10.1016/j.ijhydene.2016.02.030 . insu-01287692

\section{HAL Id: insu-01287692 \\ https://hal-insu.archives-ouvertes.fr/insu-01287692}

Submitted on 13 Jun 2016

HAL is a multi-disciplinary open access archive for the deposit and dissemination of scientific research documents, whether they are published or not. The documents may come from teaching and research institutions in France or abroad, or from public or private research centers.
L'archive ouverte pluridisciplinaire HAL, est destinée au dépôt et à la diffusion de documents scientifiques de niveau recherche, publiés ou non, émanant des établissements d'enseignement et de recherche français ou étrangers, des laboratoires publics ou privés. 


\section{Dark fermentative hydrogen production by anaerobic sludge growing on glucose and ammonium resulting from nitrate electroreduction}

Rawa Abdallah ${ }^{2 *}$, Hayet Djelal ${ }^{4,6}$, Abdeltif Amrane ${ }^{3,6}$, Walaa Sayed ${ }^{2,3,4}$, Florence Fourcade ${ }^{3,6}$, Thierry Labasque ${ }^{5,6}$, Samir Taha $^{2}$, Florence Geneste ${ }^{1,6}$, Didier Floner ${ }^{1,6}$

${ }^{1}$ Université de Rennes 1, CNRS, UMR 6226, Equipe Matière Condensée et Systèmes Electroactifs, Campus de Beaulieu, 35042 Rennes cedex, France

${ }^{2}$ Université Libanaise, EDST, Centre Azm pour la Recherche en Biotechnologie et ses Applications, LBA3B, Rue El Mitein, Tripoli, Liban

${ }^{3}$ Ecole Nationale Supérieure de Chimie de Rennes, Université de Rennes 1, CNRS, UMR 6226, 11 allée de Beaulieu, CS 50837, 35708 Rennes cedex 7, France

${ }^{4}$ Ecole des Métiers de l'Environnement, Campus de Ker Lann, 35170 Bruz, France

${ }^{5}$ Géosciences Rennes-OSUR, UMR CNRS 6118, université de Rennes 1, France

${ }^{6}$ Université Européenne de Bretagne, 5 boulevard Laënnec, 35000 Rennes, France

*Corresponding author. Tel: +961 7029235; fax: +9616 213383

E-mail address: rawaabdallah@hotmail.com (R. Abdallah) 


\begin{abstract}
The main objective of this work was to study the feasibility of biohydrogen production by heattreated anaerobic sludge with glucose as carbon substrate and ammonium as nitrogen source, obtained from the electrochemical reduction of concentrated nitrate solutions $\left(3 \mathrm{~g} \mathrm{~L}^{-1} \mathrm{NO}_{3}{ }^{-}\right)$, namely model solutions simulating those obtained after physicochemical denitrification of industrial wastewaters. Experiments were realized in bacth systems involving $125 \mathrm{~mL}$ (without $\mathrm{pH}$ control) and $3 \mathrm{~L}$ (with $\mathrm{pH}$ control) reactor, respectively.

In order to find the optimal conditions for $\mathrm{H}_{2}$ production, the first set of experiments were conducted without $\mathrm{pH}$ control at various initial $\mathrm{pH}(\mathrm{pH}$ 5.5, 6.5 and 7.5) and glucose concentrations (5-30 $\left.\mathrm{g} \mathrm{L}^{-1}\right)$; and the highest $\mathrm{H}_{2}$ yield $\left(1.1 \mathrm{~mol} \mathrm{H}_{2} \mathrm{~mol}^{-1}\right.$ glucose consumed $)$ was reached for a glucose concentration of $25 \mathrm{~g} \mathrm{~L}^{-1}$ and at $\mathrm{pH}$ 6.5. These optimal conditions were then considered to examine the effect of $\mathrm{pH}$ control on biohydrogen production, in a $3 \mathrm{~L}$ bioreactor. The $\mathrm{pH}$ control allowed a considerable improvement of the hydrogen gas conversion efficiency, which reached $2.02 \mathrm{~mol} \mathrm{H}_{2}$ $\mathrm{mol}^{-1}$ glucose consumed.
\end{abstract}

Keywords: Nitrate electro reduction; Ammonium; Anaerobic activated sludge; Dark fermentative hydrogen production; Combined process 


\section{Introduction}

Hydrogen is considered as an attractive future clean and renewable energy carrier due to its environmental-friendly conversion. Indeed, its combustion product is water and it has a high energy content [1], since the energy yield of hydrogen is $122 \mathrm{kJg}^{-1}$, namely 2.75 times that of fossil fuel [2].

During the last decades, several processes have been used for hydrogen production [3], including electrolysis of $\mathrm{H}_{2} \mathrm{O}$, thermocatalytic reformation of hydrogen rich substrates and various biological processes [4,5]. Among these methods, microbiological hydrogen production has attracted considerable attention because it has the potential to convert low cost residues or organic waste/wastewater to hydrogen [1-3]. According to the type of employed microorganisms, biological $\mathrm{H}_{2}$ production under anaerobic conditions can be classified into two different categories: dark and photo fermentation processes [6]. The most promising and widely investigated process is dark fermentation. It has more advantages than photofermentative $\mathrm{H}_{2}$ production, including lower costs since energy provided by sunlight is not required, high hydrogen production rate and simple process control with a wide range of temperature and pressure conditions which can be implemented $[7,8]$.

Theoretically, a maximum of 4 moles of hydr*ogen per mole glucose converted via the acetate pathway can be generated via dark hydrogen fermentation; however, the reported yields are typically below this value, due to the generation of by-products [9]. In addition to acetate, small organic compounds such as butyrate and ethanol are also produced, and are termed "dead-end" or “'fermentation barrier,', and limit the hydrogen yield to a maximum of $2-3 \mathrm{~mol} \mathrm{H}_{2}$

[7]. Usually, no more than one third of the total potential electrons in complex biomass can be transferred to hydrogen, while the remaining, namely two thirds, end up in the form of these fermentation by-products, enhancing therefore the total costs of biohydrogen production process. High hydrogen yields are however required to make the process economically feasible [10]. 
The most noteworthy study is that lately reported by Rivera et al. [11] in which they proved that the bio-electrochemical systems fed with dark fermentation effluents is a way forward to get higher $\mathrm{H}_{2}$ production efficiency.

Many factors must be taken into consideration for enhancing hydrogen production in fermentation systems, such as $\mathrm{pH}$, substrate concentration, inoculum, temperature and nitrogen sparging $[12,13]$. Abiotic factors such as the type of bioreactor is also of key interest, since it was demonstrated by Kumar et al. [14] that advanced fermenter configuration incorporating upstream, such as $\mathrm{H}_{2}$ production and subsequent downstream including biohydrogen recovery and purification may lead to novel and promising biohydrogen systems.

A broad spectrum of carbohydrate rich substrates have been considered to producebiohydrogen, such as starch [15], xylose, agricultural wastes [16], lignocellulose [14] and glucose [17-22]. However, the use of glucose or the conversion of raw material to glucose is favored because it is easily biodegradable by most of bacteria [12]. Nevertheless, the chosen glucose concentrations must be low enough in order to minimize $\mathrm{pH}$ changes resulting from acids produced during fermentation [23]. Indeed, it was shown that $\mathrm{pH}$ is among the major environmental factors which affects biohydrogen production due to its effect on the hydrogenase activity, the enzyme involved in the metabolism of hydrogen in most bacteria [24]; optimal initial $\mathrm{pH}$ value for biological hydrogen production is generally found to be between 5.0 and 6.5 [25]. However, optimum pH value can vary according to the carbon substrate used, from $\mathrm{pH} 9$ for sucrose [26] to $\mathrm{pH} 5.5$ for glucose [27].

Consequently, lowering production cost is still a key issue to project this technology to an industrial-scale. Nitrogen and carbon feedstock represents $30-40 \%$ total costs of fermentative hydrogen production [28]. Nitrogen is one of the most essential nutrients needed for the growth of hydrogen-producing bacteria. It is a very important component for nucleic acids, proteins and enzymes that are of great significance to the growth of hydrogen-producing bacteria. Thus, an 
appropriate level of nitrogen addition is beneficial to the growth of hydrogen-producing bacteria and to dark fermentative hydrogen production accordingly [29].

One way to make biological hydrogen production providing simultaneously economic and environmental benefits consist of the coupling the biohydrogen production to another physicochemical depollution process, such as that of nitrate ions $\left(\mathrm{NO}_{3}{ }^{-}\right)$.

$\mathrm{NO}_{3}{ }^{-}$contamination of water sources has become a serious problem around the world [30]. Nitrate causes methemoglobinemia in infants and eutrophication of water bodies [31].

The transformation of $\mathrm{NO}_{3}^{-}$to the non-toxic nitrogen gas $\left(\mathrm{N}_{2}\right)$ is the most widely used electrochemical method for nitrate removal from contaminated water [32-35], however the rate and the selectivity of the reaction are usually low, limiting therefore their utility for large scale application [36]. In this context the use of coupling process can allow to overcome these limitations.

Electrochemical and biological processes were coupled for the removal of heavy metals [37] and biorecalcitrants compounds [38,39]. However and to the authors' knowledge, their previous work was the sole study dealing with the feasibility of such coupled process to produce biohydrogen while treating nitrate ions from water [36]. On the one hand, according to the literature copper cathode $(\mathrm{Cu})$ is known to be the most efficient electrocatalyst for the electro-reduction of nitrate by mainly producing ammonium as final product $[30,40]$. On the other hand, inorganic ammonium $\left(\mathrm{NH}_{4}^{+}\right)$was the most widely investigated nitrogen source for fermentative hydrogen production $[18,22,23,41,42]$, owing to its lower cost if compared to organic nitrogen sources, such as for instance yeast extract $[43,44]$ and polypepton $[45,46]$.

For these reasons, from an environmental and economical point of view, an electrochemical reduction of nitrate to $\mathrm{NH}_{4}{ }^{+}$over $\mathrm{Cu}$ cathode can be considered as a promising and an attractive way, since it allows not only the treatment of nitrate, but also energetic valorization of the nitrate treated effluent. 
Therefore, the interest of this work does not reside only in the biological hydrogen production, but also in the finding of an alternative nitrogen source, ammonium solution resulting from nitrate electrochemical treatment, as substitute for expensive and commercial nitrogen products usually investigated in fermentative hydrogen production studies [41,44,45,47]. This should also allow to simultaneously decrease the global cost of the denitrification and the hydrogen production cost, making the hydrogen gas more available and cheaper.

In a previous study [48] the feasibility of coupling electrochemical and biological processes to destroy nitrate ions $\left(\mathrm{NO}_{3}^{-}\right)$from water while producing biohydrogen were proved.

However, the comparison of the $\mathrm{H}_{2}$ yield obtained in this study using aerobic activated sludge and ammonium solution generated electrochemically to those of the literature involving anaerobic activated sludge and performed under similar experimental conditions (batch study, glucose as a carbon source and similar optimal $\mathrm{pH}$ ) shows lower hydrogen yields. Indeed, $0.35 \mathrm{~mol} \mathrm{H}_{2} \mathrm{~mol}^{-}$

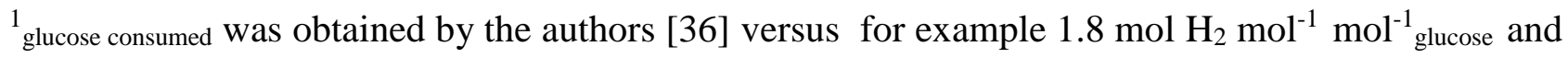
$2.2 \mathrm{~mol} \mathrm{H}_{2} \mathrm{~mol}^{-1}$ glucose obtained by Wang and Wan [49] and Lee et al. [50], respectively. The optimization of hydrogen production efficiency using more adequate inoculum, anaerobic activated sludge, and by controlling the $\mathrm{pH}$ medium was therefore the purpose of the present work.

\section{Materials and Methods}

\subsection{Electrochemical nitrates pretreatment}

All the chemicals used in this study were purchased as reagent grade from Alfa-Aesar (Schiltigheim, France).

The electrochemical pre-treatment of nitrate solutions $\left(3 \mathrm{~g} \mathrm{~L}^{-1} \mathrm{NO}_{3}{ }^{-}\right)$prepared in phosphoric acid $\left(\mathrm{H}_{3} \mathrm{PO}_{4} 10^{-2}\right.$ mol. $\left.\mathrm{L}^{-1}\right)$ and adjusted to a $\mathrm{pH}$ of 1.1 using sulfuric acid $96 \%$ has been carried out as described in a previous study [48]. These high nitrate concentrations were chosen to be similar to real effluents obtained after the treatment of drinking water contaminated by nitrate using ion 
exchange treatment methods [51,52]. This electrochemical step was based on a home-made flow cell using a copper porous material $(5.6 \mathrm{~cm}$ diameter and $0.3 \mathrm{~cm}$ thickness) as a working electrode prepared as previously described [53]. The electrolyte solution (3 $\mathrm{g} \mathrm{L}^{-1} \mathrm{NO}_{3}^{-}$in $10^{-2} \mathrm{M} \mathrm{H}_{3} \mathrm{PO}_{4}$ ) percolated the porous copper electrode at a constant flow rate of $2 \mathrm{~mL} \mathrm{~min}^{-1}$ monitored by a Gilson minipuls 2 peristaltic pumps (Middleton, WI, USA). The current intensity was generated by a home-made power supply (30 V/3 A).

To calculate the applied current intensity (A) the following relation was used:

$\mathrm{i}(\mathrm{A})=\left[\mathrm{NO}_{3}{ }^{-}\right]_{\mathrm{t}=0} \times \mathrm{d} \times\left(10^{-3} / 60\right) \times \mathrm{n} \times \mathrm{F}$

where $\left[\mathrm{NO}_{3}{ }^{-}\right]_{\mathrm{t}=0}$ is the initial nitrate concentration $\left(\mathrm{mol} \mathrm{L}{ }^{-1}\right), \mathrm{d}$ is the flow rate $\left(\mathrm{mL} \mathrm{min}^{-1}\right), \mathrm{n}$ is the number of exchanged electrons, $8 \mathrm{e}^{-}$, for the conversion of nitrate to ammonium and $\mathrm{F}$ is the Faraday's constant $(96500 \mathrm{C})$.

After only one pass through the electrochemical flow cell, the performance of the electrochemical conversion of nitrate into ammonium was evaluated using the following parameters: the chemical yield of ammonium formation $\left(\% \mathrm{X}_{\mathrm{NH} 4+}\right)$ (Eq. 2) and the selectivity based on the ammonium yield (\% $\left.\mathrm{S}_{\mathrm{NH} 4+}\right)$ (Eq. 3).

$\% \mathrm{X}_{\mathrm{NH} 4+}=\left(\left[\mathrm{NH}_{4}^{+}\right]_{\mathrm{t}} \times 100\right) /\left[\mathrm{NO}_{3}^{-}\right]_{\mathrm{t}=0}$

$\% \mathrm{~S}_{\mathrm{NH} 4+}=\left(\left[\mathrm{NH}_{4}^{+}\right]_{\mathrm{t}} \times 100\right) /\left(\left[\mathrm{NO}_{3}{ }^{-}\right]_{\mathrm{t}=0}-\left[\mathrm{NO}_{3}{ }^{-}\right]_{\mathrm{t}}\right)$

where $[X]_{t=0}$ and $[X]_{t}$ are the concentrations of $\mathrm{NH}_{4}{ }^{+}$or $\mathrm{NO}_{3}{ }^{-}$in solution at initial time $\mathrm{t}_{0}$ and a given time $\mathrm{t}(\mathrm{s})$. All the concentrations are in $\mathrm{mol} \mathrm{L}^{-1}$.

The effluents collected after nitrate electrochemical reductions were used for subsequent biohydrogen production tests.

\subsection{Seed sludge and medium composition}

The anaerobic microflora used in this study was collected from an anaerobic digester for methane production located in a local municipal wastewater treatment plant (Beaurade, Rennes, France). Prior to use, the seed sludge was first washed four times with tap water, and was then 
sieved to remove sand, stone and other coarse matters. Thereafter a heat treatment of sludge at $102^{\circ} \mathrm{C}$ for 90 min was performed in order to enrich $\mathrm{H}_{2}$-producing bacteria and to inhibit the hydrogenotrophic methanogens activity.

One liter of the hydrogen production medium for this inoculum contained:

$360 \mathrm{mg} \mathrm{MgSO} 4.7 \mathrm{H}_{2} \mathrm{O}, 48 \mathrm{mg} \mathrm{NiCl} 2.6 \mathrm{H}_{2} \mathrm{O}, 66 \mathrm{mg} \mathrm{CaCl}_{2} .2 \mathrm{H}_{2} \mathrm{O}, 50 \mathrm{mg} \mathrm{FeCl}$, $30 \mathrm{mg} \mathrm{MnCl}_{2} .4 \mathrm{H}_{2} \mathrm{O}$,

$21 \mathrm{mg} \mathrm{CoCl} .6 \mathrm{H}_{2} \mathrm{O}, 23 \mathrm{mg} \mathrm{ZnCl}, 10 \mathrm{mg} \mathrm{CuCl} 2.2 \mathrm{H}_{2} \mathrm{O}, 175 \mathrm{mg} \mathrm{K} 2 \mathrm{HPO} 4$ and $175 \mathrm{mg} \mathrm{K}{ }_{2} \mathrm{HPO} 4$ [27].

In all experiments the glucose and the electrolyzed solution collected after electrochemical treatment of the nitrate solution $\left(3 \mathrm{~g} \mathrm{~L}^{-1} \mathrm{NO}_{3}{ }^{-}\right.$, namely $\left.484 \mathrm{mmol} \mathrm{L}{ }^{-1}\right)$ were used as a carbon and nitrogen sources, respectively.

\subsection{Batch tests in $125 \mathrm{~mL}$ glass bottles}

The batch tests were carried out to investigate the effects of initial $\mathrm{pH}$ and glucose concentration on biohydrogen production experiments. $125 \mathrm{~mL}$ glass bottles with a working volume of $100 \mathrm{~mL}$ were used for the batch tests. All experiments were carried out in duplicate; the mean values with the corresponding error were reported in the figures.

(1) The $\mathrm{pH}$ of the medium culture was buffered using $0.07 \mathrm{~mol} \mathrm{~L}^{-1}$ of 2 -(N-morpholino) ethanesulfonic acid monohydrate (MES), an inexpensive and nontoxic buffer [10,23].

(2) The reactors were inoculated with the heat-treated sludge at $4 \mathrm{~g} \mathrm{~L}^{-1}$.

(3) To provide anaerobic conditions, the headspace was replaced with nitrogen gas (purged for 5 $\min )$.

(4) Finally, bottles were incubated in a shaker (New Brunswick, Innova 40) at $180 \mathrm{rpm}$ and at a constant temperature $\left(37^{\circ} \mathrm{C} \pm 1\right)$. This temperature was adopted because the majority of biohydrogen production studies was conducted under mesophilic conditions, typically in the range of $35-37{ }^{\circ} \mathrm{C}[18,21,27,41,54]$. This $\mathrm{pH}$ range is favorable for the cultivation and the 
hydrogen-producing activity of microorganisms. Consequently, it increases the production yield of hydrogen from residual organic substrates [55].

Two series of experiments were conducted to study $\mathrm{H}_{2}$ production.

Due to the fact that an initial glucose concentration of $15 \mathrm{~g} \mathrm{~L}^{-1}$ was previously found as the optimal carbon concentration for biological hydrogen production using aerobic activated sludge [48], this glucose concentration was considered for the first series of experiments, which was dedicated to examine the effect of initial $\mathrm{pH}$ values on $\mathrm{H}_{2}$ production efficiency. Three different $\mathrm{pH}$ values (5.5, 6.5 and 7.5) were chosen, which were adjusted using $0.07 \mathrm{~mol} \mathrm{~L}^{-1} \mathrm{MES}$ buffer.

In the second experimental series, the effect of the initial glucose concentration was studied using different amounts of glucose $\left(5,10,15,20,25\right.$ and $\left.30 \mathrm{~g} \mathrm{~L}^{-1}\right)$.

The $\mathrm{pH}$ measurements were performed using a 9165BN pH electrode connected to an Orion-828 $\mathrm{pH}$ Analyzer (Orion Research Inc., Beverly, MA, USA).

Hydrogen yields were calculated based on the following equation:

$\mathrm{H}_{2}$ yields $\left(\mathrm{mol} \mathrm{H} \mathrm{mol}^{-1}\right.$ glucose consumed $)=\mathrm{H}_{2}$ produced (mol) / Glucose consumed (mol)

\subsection{Batch reactor experiments in $3 L$ bioreactor}

The optimal conditions (glucose concentration and $\mathrm{pH}$ ) determined above in the section 2.3, were considered thereafter to produce biohydrogen in a 3L fermentor (New Brunwick Scientific BioFlo 110) operated in batch mode and an inlet substrate concentration of $25 \mathrm{~g}$ glucose $\mathrm{L}^{-1}$. The bioreactor was filled with 1.5. L (working volume) with culture medium beforehand sparged with nitrogen gas to achieve anaerobic conditions and inoculated with heat-treated anaerobic sludge (4 g $\left.\mathrm{L}^{-1}\right)$. The $\mathrm{pH}$ of the mixed liquor was kept constant at 6.5 by feeding $4 \mathrm{~mol} \mathrm{~L} \mathrm{LaOH}^{-1} \mathrm{NaO} 2 \mathrm{~mol} \mathrm{~L}-1$ $\mathrm{HCl}$ solutions via respective peristaltic pumps. The temperature was kept at $37^{\circ} \mathrm{C}$ with a temperature controller, and the agitation rate was $180 \mathrm{rpm}$. A biogas sampling port was installed in the reactor to allow direct biogas sampling with a syringe. For kinetic studies of batch anaerobic 
hydrogen production, samples $(2 \mathrm{ml})$ were withdrawn periodically from the reactor with a needle inserted through a port on the top surface).

\subsection{Analytical methods}

The liquid samples were analyzed for biomass concentration, residual glucose concentration, volatile fatty acids and solvents. Biogas percentages in the reactor headspace were also measured.

\subsubsection{Biomass concentration (Microbial growth analysis)}

Biomass growth was measured in terms of Suspended Solids (SS, $\mathrm{g} \mathrm{L}^{-1}$ ). Where $5 \mathrm{~mL}$ of sludge was disposed in a previously weighed porcelain cup (P1) and placed in an oven at $105^{\circ} \mathrm{C}$ until having a constant weight (P2). The Suspended solids were calculated according to Eq.5:

$\mathrm{SS}\left(\mathrm{g} \mathrm{L}^{-1}\right)=(\mathrm{P} 2-\mathrm{P} 1) / 0.005$

2

\subsubsection{Liquid samples}

$\mathrm{NH}_{4}{ }^{+}$concentrations in solution resulting from nitrate electroreduction and that remained after biological hydrogen production were measured by UV-vis spectroscopy as reported elsewhere [56-58]. $\mathrm{NO}_{3}{ }^{-}$and $\mathrm{NO}_{2}{ }^{-}$ions were determined by ion chromatography (Dionex 120) equipped with a chemical suppressor (ASR 300 -ultra 4 mm) and a Dionex on Pac AS19 Anion Exchange column (4x250mm). $2 \mathrm{~mol} \mathrm{~L}^{-1} \mathrm{KOH}$ was used as eluent at a flow rate of $1.04 \mathrm{~mL} \mathrm{~min}^{-1}$.

Gas chromatography-mass spectrometry (GC/MS) measurements of the soluble microbial products (SMPs) in the fermentation solution were performed with a Perkin Elmer Clarus 500 apparatus (California, United States) coupled with a Variance CB-FFAP $0.25 \mu \mathrm{m}$ column $(25 \mathrm{~m} \times 0.15 \mathrm{~mm})$. Compounds identification was conducted with the help of a list database (Nist). GC/MS analysis showed that acetic, butyric, isobutyric acids and ethanol were the main liquid metabolites (data not shown). Other compounds were detected at trace levels, such as acetaldehyde. 
Analysis of fermentation by-products (volatile fatty acids (VFAs), lactic acid and ethanol) contained in the aqueous phase was carried out by gas chromatography (GC Thermo Focus) equipped with a flame ionization detector (FID) and a FFAP-CB column $(15 \mathrm{~m} \times 0.1 \mathrm{~mm}, 0.1 \mu \mathrm{m})$ specially adapted to the separation of volatile fatty acids. In order to reduce the presence of suspended solids, liquid samples were centrifuged at $8000 \mathrm{rpm}$ for $10 \mathrm{~min}$ at $4^{\circ} \mathrm{C}$ then acidified by 6 mol $\mathrm{L}^{-1} \mathrm{HCl}$ and filtered through $0.25 \mu \mathrm{m}$ membrane before analysis. The addition of $\mathrm{HCl}$ solution to the sample allows the protonation of the volatile fatty acids to be analyzed. The injector and detector were operated at 200 and $250{ }^{\circ} \mathrm{C}$, respectively. The oven was held at $90^{\circ} \mathrm{C}$ for $0.5 \mathrm{~min}$; then heated to $200{ }^{\circ} \mathrm{C}$ with a ramp of $40{ }^{\circ} \mathrm{C} \mathrm{min}^{-1}$ and maintained at $200{ }^{\circ} \mathrm{C}$. Nitrogen was used as carrier gas with a flow rate of $.2 \mathrm{~mL} \mathrm{~min}^{-1}$. The column head pressure was controlled at $35 \mathrm{~Pa}$.

Glucose consumption was quantified using a high performance liquid chromatography (HPLC) system (Shimadzu LC-20AD) which was equipped with an ions exclusion column HPX-87H (300 x7.8 mm; Bio-Rad, Hercules, CA, USA), a Shimadzu RIO-6A refractive index (RI) detector and a photodiode array (PDA) analyzer. $0.5 \mathrm{~mol} \mathrm{~L}^{-1} \mathrm{H}_{2} \mathrm{SO}_{4}$ was used as mobile phase at a flow rate of $0.7 \mathrm{~cm}^{3} \mathrm{~min}^{-1}$ (waters pump, Milford, MA, USA).

$\mathrm{CO}_{2}$ and $\mathrm{N}_{2} \mathrm{O}$ were measured as specified in the following section (2.5.3).

\subsubsection{Biogas content}

The proportion of hydrogen and methane in the produced gas was determined by a $\mu \mathrm{GC}$ (Agilent Micro GC3000, SRA Instruments) equipped with a thermal conductivity detector (TCD) and a stainless steel column $(30 \mathrm{~m})$ packed with molecular sieve $5 \AA$. The temperatures of the column and detector were maintained at $60^{\circ} \mathrm{C}$ and $100^{\circ} \mathrm{C}$, respectively. In order to determine the proportion of carbon dioxide and nitrous oxide, the same gas chromatograph (Agilent Micro GC3000, SRA Instruments) was used, equipped with a TCD and a stainless steel column $(10 \mathrm{~m})$ packed with Porapak Q. The temperatures of the column and the detector were maintained at $70^{\circ} \mathrm{C}$ and $100^{\circ} \mathrm{C}$, 
respectively. Pure helium (6.0 quality) was used as carrier gas and the pressure through the columns was fixed at $40 \mathrm{psi}$.

\section{Results and Discussion}

\subsection{Batch study in $125 \mathrm{~mL}$ glass bottles without $\mathrm{pH}$ control}

\subsubsection{Effect of the initial $p H$}

Nitrate electrolysis was performed with $\mathrm{NO}_{3}{ }^{-}$solutions of $3 \mathrm{~g} \mathrm{~L}^{-1}$, phosphoric acid $\left(10^{-2} \mathrm{M}\right.$ $\left.\mathrm{H}_{3} \mathrm{PO}_{4}\right)$ was used as supporting electrolytes. It is noteworthy that such electrolytes were chosen to prevent the addition of a phosphorus source, needed for the subsequent bacterial culture. Using the optimal conditions determined in a previous study [53] namely a current intensity of (1.24 A) applied between the copper porous electrode and two counter electrodes made of fine platinum grids and a flow rate of $2 \mathrm{~mL} \mathrm{~min}{ }^{-1}$. After only one pass of concentrated nitrate solutions through the flow cell, the $\mathrm{NO}_{3}{ }^{-}$electroreduction to ammonium was quasi quantitative in the acidic solution with a \% $\mathrm{X}_{\mathrm{NH} 4+}$ of $92.5 \%$, namely a very high $\mathrm{NH}_{4}{ }^{+}$ions selectivity $\left(\% \mathrm{~S}_{\mathrm{NH} 4+}=98.7 \%\right)$ corresponding to $0.86 \mathrm{~g} \mathrm{~L}^{-1} \mathrm{NH}_{4}^{+}$. Ammonium solutions were then tested as a nitrogen source to produce $\mathrm{H}_{2}$ in a batch system.

In this context, three ammonium solutions at different initial $\mathrm{pH}$ values $(5.5,6.5$ and 7.5$)$ were inoculated with anaerobic sludge pretreated thermally. For each one, the initial glucose concentration was set at $15 \mathrm{~g} \mathrm{~L}^{-1}$, optimal glucose concentration for hydrogen production previously recorded in the case of aerobic sludge [48]. Analysis of the residual glucose concentration after 48 hours of dark fermentation shows similar trend as the yields of $\mathrm{H}_{2}$ related to the initial $\mathrm{pH}$, namely a peak for 6.5 initial $\mathrm{pH}$ (Figure 1). 


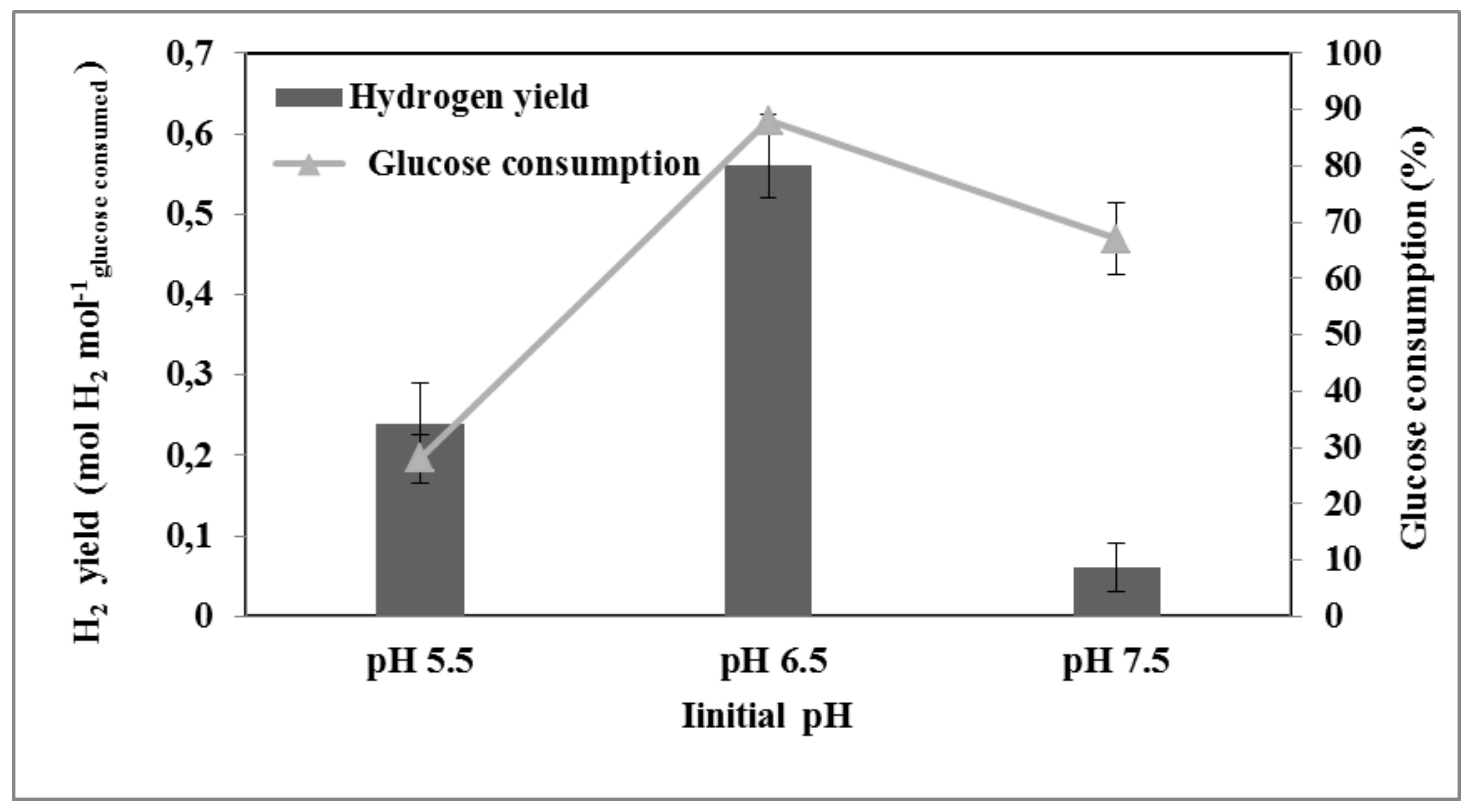

Figure 1: $\mathrm{H}_{2}$ yields and glucose consumption versus the initial $\mathrm{pH}$ (Error bars are based on duplicate experiments. Initial glucose concentration: $\left.15 \mathrm{~g} \mathrm{~L}^{-1}\right)$.

Indeed, at $\mathrm{pH}=6.5,88 \%$ of the initially added glucose $\left(15 \mathrm{~g} \mathrm{~L}^{-1}\right)$ was consumed and hydrogen yield reached $0.56 \mathrm{~mol} \mathrm{H}_{2} \mathrm{~mol}^{-1}$ glucose consumed (Figure 1).

In parallel with hydrogen production, high ammonium assimilation yields were also observed, they varied between $75 \%$ and $85 \%$ after $48 \mathrm{~h}$ culture (Table 1), with a maximum of $85 \%$ obtained at $\mathrm{pH}$ 6.5 .

Another important parameter to be considered is the quality of the produced biogas, that should mainly contain $\mathrm{H}_{2}$; it is therefore important to minimize as much as possible other gases. Analyses of biogas by microGC showed the absence of $\mathrm{H}_{2} \mathrm{~S}$ (hydrogen competitor), $\mathrm{CH}_{4}$ and $\mathrm{N}_{2} \mathrm{O}$ formation throughout experiments, including the biotic controls. But in contrast to the control realized without addition of glucose and nitrogen sources wich was free of $\mathrm{H}_{2}$ and $\mathrm{CO}_{2}$, at the three $\mathrm{pH}$ values the produced gas contained only $\mathrm{H}_{2}$ and $\mathrm{CO}_{2}$. The molar ratio $\left(\mathrm{CO}_{2} / \mathrm{H}_{2}\right)$ is a good indicator for the purity of biogas; according to table 1, a sharp minimum (0.1) was obtained for an initial $\mathrm{pH}$ of 6.5 . 
Table 1 : Summary of the results obtained after $48 \mathrm{~h}$ culture in $125 \mathrm{~mL}$ batch reactors at different initial $\mathrm{pH}$ values. Error bars are based on duplicate experiments; Initial glucose concentration: $15 \mathrm{~g}$ $\mathrm{L}^{-1}$.

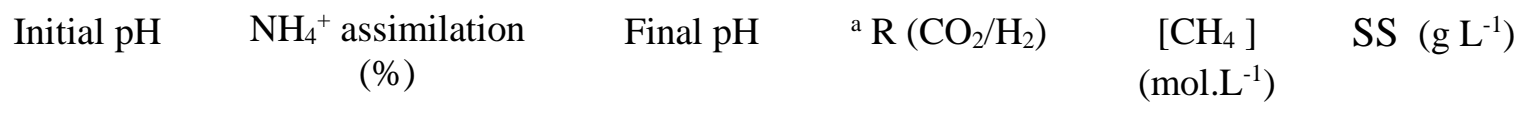

$\begin{array}{llllll}5.5 & 75 \pm 2.6 & 5.1 \pm 0.1 & 1.1 \pm 0.1 & 0.0 & 15.0 \pm 1.5 \\ 6.5 & 85 \pm 3.2 & 4.98 \pm 0.2 & 0.1 \pm 0.01 & 0.0 & 14.0 \pm 4.5 \\ 7.5 & 80 \pm 2.4 & 5.53 \pm 0.3 & 1.5 \pm 0.2 & 0.0 & 15.5 \pm 2.8\end{array}$

$\left.{ }^{\text {a }}\left(\mathrm{CO}_{2} / \mathrm{H}_{2}\right)\right)$ is the ratio between the molar concentrationsof produced $\mathrm{CO}_{2}$ to $\mathrm{H}_{2}$ at different $\mathrm{pH}$.

In the studied $\mathrm{pH}$ range (Table 1), whatever the initial $\mathrm{pH}$ value, the final biomass concentration remained roughly similar, namely close to $14-15 \mathrm{~g} \mathrm{~L}^{-1}$. However, the differences between the final $\mathrm{pH}$, even if limited, can lead to significant changes in the metabolic activity of hydrogen producing bacteria, characterized by very different amounts of produced hydrogen and carbon dioxide. This behavior is probably due to a change in metabolic pathways of the bacterial consortium; pathway that promotes or not hydrogen production. To confirm this hypothesis the results of an analytical monitoring of soluble microbial products (SMPs) resulting from glucose fermentation under different initial $\mathrm{pH}$ were shown in table 2 . As shown in table 2 , at $\mathrm{pH} 5.5$ the main soluble products were acetic acid followed by butyric and isobutyic acids; while low amounts of acetaldehyde were detected in the three media. At $\mathrm{pH} 5.5$, hydrogen production was mainly accompanied by acetic acid and ethanol formation and then, with the increase of the medium $\mathrm{pH}$, the metabolism was gradually shifted to the acetic acid / butyric acid pathway with a decrease of ethanol formation. In summary and as illustrated by table 2, with the increase of the initial $\mathrm{pH}$, the 
concentrations of acetic and butyric acids progressively increased, while that of ethanol decreased rapidly.

Table 2: Residual acids, solvents and alcohols in solution produced after $48 \mathrm{~h}$ culture under different initial pH values. Uncertainties are based on duplicate experiments. Initial glucose concentration: $15 \mathrm{~g} \mathrm{~L}^{-1}$.

\begin{tabular}{cccccc}
\hline Initial $\mathrm{pH}$ & $\begin{array}{c}\text { Acetaldehyde } \\
\left(\mathrm{mg} \mathrm{L}^{-1}\right)\end{array}$ & $\begin{array}{c}\text { Ethanol } \\
\left(\mathrm{mg} \mathrm{L}^{-1}\right)\end{array}$ & $\begin{array}{c}\text { Acetic acid } \\
\left(\mathrm{mg} \mathrm{L}^{-1}\right)\end{array}$ & $\begin{array}{c}\text { Butyric acid } \\
\left(\mathrm{mg} \mathrm{L}^{-1}\right)\end{array}$ & $\begin{array}{c}\text { Isobutyric acid } \\
\left(\mathrm{mg} \mathrm{L}^{-1}\right)\end{array}$ \\
\hline 5.5 & $26.6 \pm 1.5$ & $693.0 \pm 32.0$ & $574.5 \pm 4.3$ & $141.6 \pm 12.0$ & $45.6 \pm 12.0$ \\
6.5 & $7.1 \pm 0.5$ & $153.9 \pm 11.0$ & $1520.7 \pm 24.0$ & $520.1 \pm 16.0$ & $299.9 \pm 8.0$ \\
7.5 & $1.4 \pm 0.1$ & $40.0 \pm 4.0$ & $3200.0 \pm 18.0$ & $802.5 \pm 5.4$ & $416.0 \pm 5.4$ \\
\hline
\end{tabular}

It is noteworthy that the final $\mathrm{pH}$ values were very close (Table 1), despite different initial $\mathrm{pH}$. The $\mathrm{pH}$ change increased from $7.3 \%$ to $26.0 \%$ for $\mathrm{pH}$ increasing from 5.5 to 7.5 . These $\mathrm{pH}$ changes corresponded to the production of high concentrations of organic acids (Table 2) decreasing therefore the $\mathrm{pH}$ of the buffered $\left(0.05 \mathrm{~mol} \mathrm{~L}^{-1} \mathrm{MES}\right)$ solutions. From the comparison of the soluble fermentation products (Table 2) and hydrogen yield profiles (Figure 1) under different initial $\mathrm{pH}$, it is clear that the low hydrogen production recorded at $\mathrm{pH}=5.5$ can be related to the high production of ethanol $\left(639 \mathrm{mg} \mathrm{L}^{-1}\right)$. Indeed, this ethanol production in the reactor indicates that at this initial $\mathrm{pH}$ value, either spore-forming hydrogen producers were not the dominant community, or that the bacteria began utilizing an ethanol producing metabolic pathway. This pathway, via acetaldehyde as an intermediate, does not produce $\mathrm{H}_{2}$ (Eq.6) like the acetate and butyrate pathways do as shown in Eq.7 and Eq.8

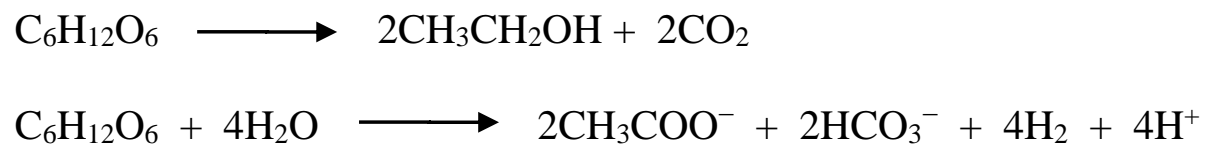


The latter supposition was clearly confirmed by table 2, which showed that the highest amount of acetaldehyde $\left(26.6 \mathrm{mg} \mathrm{L}^{-1}\right)$ was recorded at $\mathrm{pH}$ 5.5. The low levels of acetic and butyric acids detected at $\mathrm{pH} 5.5$ proved that these hydrogen-producing pathways were not being utilized. In contrast, the high levels of acetic acid in the reactor running at $\mathrm{pH} 6.5$ were indicative of the highest hydrogen yield $\left(0.56 \mathrm{~mol} \mathrm{H}_{2} \mathrm{~mol}^{-1}\right.$ glucose consumed $)$. These results are in agreement with those obtained by Fang and Liu [17], which proved that acetic acid production was favored at $\mathrm{pH} 6.5$, while a $\mathrm{pH}$ decrease in the biohydrogen productivity accompanied by a significant increase in the level of volatile fatty acids (VFA) (Table 2) and a $\mathrm{pH}$ decrease of two units from the initial $\mathrm{pH}$ were observed (Table 1). These results can be interpreted by the fact that the excessive self-production of volatile fatty acids, especially acetic acid at $\mathrm{pH} 7.5$, inhibited the growth of hydrogen-producing bacteria reducing therefore the $\mathrm{H}_{2}$ production efficiency [59].

Accordingly, studying the $\mathrm{pH}$ effect on biological hydrogen production and hydrogenase activity in the range of $\mathrm{pH}$ values varying from 5 to 8 and in similar conditions than those considered in the present study (glucose as carbon source, $37^{\circ} \mathrm{C}$ and in batch mode). Xiao et al. [22] found that the activity of hydrogenase decreased significantly with increasing culture $\mathrm{pH}$ and that weak acidic conditions favored hydrogen production.

All of these results proved that the initial $\mathrm{pH}$ have a considerable effect on the hydrogen production metabolism of heat-treated anaerobic sludge.

$\mathrm{H}_{2}$ could be directly utilized during the formation of propionic acid according to the following equation (Eq.9) [60] :

$\mathrm{C}_{6} \mathrm{H}_{12} \mathrm{O}_{6}+2 \mathrm{H}_{2} \longrightarrow 2 \mathrm{CH}_{3} \mathrm{CH}_{2} \mathrm{COOH}+2 \mathrm{H}_{2} \mathrm{O}$

In this study, propionic acid was absent, which suggests that the thermal pre-treatment was successful and that the conditions used were not favorable for the growth of bacteria producing this acid. Similarly lactic acid, associated with zero- $\mathrm{H}_{2}$ pathways [61] was also not detected. 
Concerning the variation of the ratios $\mathrm{R}\left(\mathrm{CO}_{2} / \mathrm{H}_{2}\right)$ obtained at various $\mathrm{pH}$, table 1 showed that the lowest ratio $(0.1)$ was recorded at $\mathrm{pH} 6.5$, which can be linked to the formation of a significant amount of organic acids, particularly in the form of acetic acid (Table 2). However, the increase of this ratio for an initial $\mathrm{pH}$ higher than 6.5, reflected an increase in the amount of $\mathrm{CO}_{2}$ produced and hence a decline of the organic carbon, also mostly found in the form of acetic acid (Table 1). The increase of this ratio $\mathrm{R}\left(\mathrm{CO}_{2} / \mathrm{H}_{2}\right)$ for $\mathrm{pH}$ below 6.5 indicated a $\mathrm{CO}_{2}$ increase to the detriment of organic carbon which was predominantly found in the form of ethanol. Therefore at an initial $\mathrm{pH}$ equal to 6.5 the lowest amount of $\mathrm{CO}_{2}$ and the highest biohydrogen production yields were recorded. Moreover, the absence of hydrogen production in the biotic control illustrated the absence of nutrient solubilization by thermal pretreatment of sewage.

In conclusion, an initial $\mathrm{pH}$ of 6.5 seems favorable to the production of hydrogen by heat treated anaerobic sludge. This result is in agreement with those of Karadag et al. [18] and Oh et al. [23] ; in similar conditions to those considered in this work they obtained 6.2 and 6.5 as optimal initial $\mathrm{pH}$ values, respectively. Therefore a $\mathrm{pH}$ of 6.5 was considered afterward to study the effect of the initial glucose concentration on hydrogen production.

\subsubsection{Effect of the initial glucose concentration}

In order to find the optimal glucose concentration for biohydrogen production, five different glucose concentrations $\left(5,10,15,20,30 \mathrm{~g} \mathrm{~L}^{-1}\right)$ were evaluated. The initial $\mathrm{pH}$ was set at 6.5. According to figure 2, it is clear that the biohydrogen productivity increased with glucose concentration to reach a maximum value of $1.1 \mathrm{~mol} \mathrm{H}_{2} \mathrm{~mol}^{-1}$ glucose consumed equivalent to $0.128 \mathrm{~mol} \mathrm{~L}^{-}$ ${ }^{1}$ of hydrogen at an initial glucose concentration of $25 \mathrm{~g} \mathrm{~L}^{-1}$. 


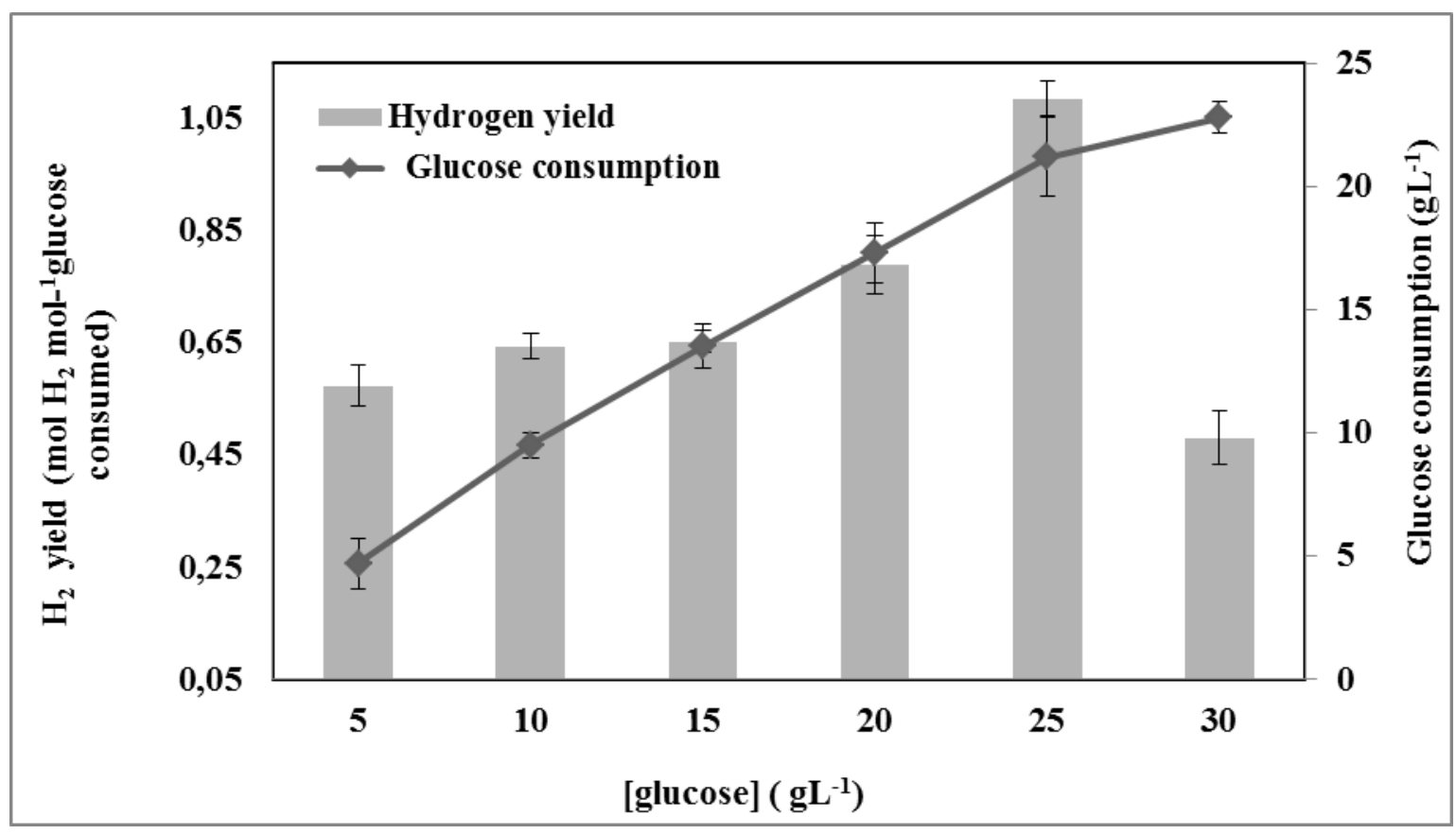

Figure 2: Effect of initial glucose concentration on $\mathrm{H}_{2}$ production by heat treated anaerobic sludge after $48 \mathrm{~h}$ culture. Errors are based on duplicate experiments (Initial $\mathrm{pH}=6.5$ ).

Beyond $25 \mathrm{~g} \mathrm{~L}^{-1}$ glucose, biohydrogen production dropped very strongly and was quickly halved, at $30 \mathrm{~g} \mathrm{~L}^{-1}$ of glucose (this decrease will be discussed below). From this, the increase of hydrogen production can be related to the amount of carbon substrate. Table 3 showed that up to $10 \mathrm{~g} \mathrm{~L}^{-1}$, glucose is the limiting factor. Ammonium assimilation profiles (Table 3) were in accordance with hydrogen production (Figure 2). Ammonium became the limiting factor from $25 \mathrm{~g} \mathrm{~L}^{-1}$ of glucose (98\%). Bacterial growth was also favored; since it increased from $10.5 \mathrm{~g} \mathrm{~L}^{-1}$ to $24 \mathrm{~g} \mathrm{~L}^{-1}$ with the increase of the initial glucose content from 5 to $25 \mathrm{~g} \mathrm{~L}^{-1}$. 
Table 3: Biohydrogen production by heat treated anaerobic sludge after $48 \mathrm{~h}$ culture as function of the initial concentration of glucose. Uncertainties are based on duplicate experiments. (Initial $\mathrm{pH}=$ $6.5)$.

\begin{tabular}{|c|c|c|c|c|c|}
\hline $\begin{array}{c}\text { Glucose } \\
\left(\mathrm{g} \mathrm{L}^{-1}\right)\end{array}$ & $\begin{array}{c}\mathrm{NH}_{4}{ }^{+} \text {assimilation } \\
(\%)\end{array}$ & $\begin{array}{c}\text { Final } \\
\text { pH }\end{array}$ & ${ }^{\mathrm{a}} \mathrm{R}_{\mathrm{CO} 2 / \mathrm{H} 2}$ & $\begin{array}{c}{\left[\mathrm{CH}_{4}\right]} \\
\left(\mathrm{mol} \mathrm{L}^{-1}\right)\end{array}$ & $\begin{array}{c}\mathrm{SS} \\
\left(\mathrm{g} \mathrm{L}^{-1}\right)\end{array}$ \\
\hline 5 & $41.1 \pm 2.1$ & $5.8 \pm 0.1$ & $0.4 \pm 0.002$ & 0.0 & $10.5 \pm 3.9$ \\
\hline 10 & $59.7 \pm 3.5$ & $4.7 \pm 0.2$ & $0.2 \pm 0.005$ & 0.0 & $16.0 \pm 0.8$ \\
\hline 15 & $74.4 \pm 0.8$ & $4.8 \pm 0.3$ & $0.2 \pm 0.002$ & 0.0 & $18.0 \pm 0.5$ \\
\hline 20 & $78.2 \pm 4.6$ & $4.9 \pm 0.2$ & $0.1 \pm 0.003$ & 0.0 & $20.0 \pm 3.3$ \\
\hline 25 & $98.8 \pm 3.1$ & $5.0 \pm 0.4$ & $0.025 \pm 0.0006$ & 0.0 & $21.0 \pm 1.9$ \\
\hline 30 & $98 \pm 0.3$ & $4.8 \pm 0.1$ & $0.13 \pm 0.007$ & 0.0 & $21.5 \pm 0.5$ \\
\hline
\end{tabular}

$\left.{ }^{a} \mathrm{R}\left(\mathrm{CO}_{2} / \mathrm{H}_{2}\right)\right)$ is the ratio between the concentration in mole $\mathrm{L}^{-1}$ of produced $\mathrm{CO}_{2}$ and $\mathrm{H}_{2}$ at different $\mathrm{pH}$.

In conclusion for an initial glucose concentration lower than $15 \mathrm{~g} \mathrm{~L}^{-1}$, glucose was the growthlimiting factor; while ammonium was not limiting until $25 \mathrm{~g} \mathrm{~L}^{-1}$ glucose.

Bacterial growth increased with the increase in substrate concentration up to $25 \mathrm{~g} \mathrm{~L}^{-1}$ glucose. A maximum of $21 \mathrm{~g} \mathrm{~L}^{-1} \mathrm{SS}$ was attained at $25 \mathrm{~g} \mathrm{~L}^{-1}$ glucose. It is noteworthy that whatever the initial glucose concentration, biogas consisted mainly of hydrogen and carbon dioxide (Table 3); nitrogen gas was probably also formed but it could not be quantified. In fact each culture medium was previously deaerated with nitrogen gas, making therefore the analysis of nitrogen gas impossible because this latter was formed in very small amount compared to that used for deaeration. Finally and as above (first series of experiments), since no trace of methane gas or $\mathrm{N}_{2} \mathrm{O}$ was detected during all the experiments, the parameter $\mathrm{R}\left(\mathrm{CO}_{2} / \mathrm{H}_{2}\right)$ can characterize the purity of biogas. At $\mathrm{pH}=6.5$ and independently of the initial glucose concentration, the amount of the produced carbon dioxide 
remained very low compared to the quantity of biohydrogen. Ratio values must match glucose concentration which gives: $\mathrm{R}\left(\mathrm{CO}_{2} / \mathrm{H}_{2}\right)$ varied from 0.025 to 0.4 for initial values of glucose ranging from 5 to $25 \mathrm{~g} \mathrm{~L}^{-1}$ (Table 3). Beyond $25 \mathrm{~g} \mathrm{~L}^{-1}$ glucose, the ratio $\mathrm{R}\left(\mathrm{CO}_{2} / \mathrm{H}_{2}\right)$ decreased again until 0.13. These ratios were much lower than those registered at $\mathrm{pH} 5.5$ and 7.5 (Section 3.1.1), which justifies once more the choice of the $\mathrm{pH}$ (6.5). The concentrations of the various metabolites measured in the liquid phase are shown in Table 4.

Table 4: Residual acids, solvents and alcohols in solution produced after $48 \mathrm{~h}$ at different initial glucose concentrations. Uncertainties are based on duplicate experiments (initial pH 6.5).

\begin{tabular}{cccccc}
\hline $\begin{array}{c}\text { Glucose } \\
\left(\mathrm{g} \mathrm{L}^{-1}\right)\end{array}$ & $\begin{array}{c}\text { Acetaldehyde } \\
\left(\mathrm{mg} \mathrm{L}^{-1}\right)\end{array}$ & $\begin{array}{c}\text { Ethanol } \\
\left(\mathrm{mg} \mathrm{L}^{-1}\right)\end{array}$ & $\begin{array}{c}\text { acetic acid } \\
\left(\mathrm{mg} \mathrm{L}^{-1}\right)\end{array}$ & $\begin{array}{c}\text { Butyric acid } \\
\left(\mathrm{mg} \mathrm{L}^{-1}\right)\end{array}$ & $\begin{array}{c}\text { Isobutyric acid } \\
\left(\mathrm{mg} \mathrm{L}^{-1}\right)\end{array}$ \\
\hline 5 & $4.2 \pm 1.6$ & $825 \pm 101.5$ & $437 \pm 29.6$ & $60 \pm 13.0$ & $78 \pm 23.9$ \\
10 & $2.1 \pm 0.6$ & $515 \pm 16.6$ & $874 \pm 84.4$ & $30 \pm 4.2$ & $156 \pm 18.2$ \\
15 & $7.1 \pm 3.8$ & $154 \pm 50.3$ & $1521 \pm 203.4$ & $300 \pm 36.4$ & $520 \pm 59.7$ \\
20 & $4.3 \pm 0.3$ & $126 \pm 25.1$ & $1755 \pm 219.1$ & $554 \pm 56.0$ & $1945 \pm 191.6$ \\
25 & $10.7 \pm 3.0$ & $111 \pm 17.2$ & $2101 \pm 419.5$ & $419 \pm 85.0$ & $1158 \pm 265.8$ \\
30 & $3.5 \pm 1.1$ & $25 \pm 2.3$ & $3157 \pm 321.0$ & $1320 \pm 199.4$ & $1543 \pm 79.4$ \\
\hline
\end{tabular}

At an initial glucose concentration of $5 \mathrm{~g} \mathrm{~L}^{-1}$ bioydrogen production was accompanied mainly by the formation of ethanol $\left(825 \mathrm{mg} \mathrm{L}^{-1}\right)$; with the increase of the glucose concentration the metabolism gradually moved towards acetic and butyric acids pathway. As shown in table 4, the concentrations of acetic, butyric and isobutyric acids increased with the initial content of glucose, while that of ethanol decreased rapidly beyond $5 \mathrm{gL}^{-1}$ glucose. This behavior is in agreement with the increase of the hydrogen production yield with a maximum $\left(1.1 \mathrm{~mol} \mathrm{H}_{2} \mathrm{~mol}^{-1}\right.$ glucose consumed $)$ obtained for $25 \mathrm{~g} \mathrm{~L}^{-1}$ of glucose (Figure 2). However, for $30 \mathrm{~g} \mathrm{~L}^{-1}$ glucose the excessive production 
of acetic acid (3157 $\left.\mathrm{mg} \mathrm{L}^{-1}\right)$ inhibited the hydrogen production metabolism, which resulted in a drop of hydrogen production efficiency.

Finally, a $\mathrm{pH}$ of 6.5 and an initial glucose concentration of $25 \mathrm{~g} \mathrm{~L}^{-1}$ appeared to be the optimal conditions for the production of hydrogen. These conditions oriented the glucose metabolism toward the production of acetic acid, which corresponds to the biohydrogen production pathway. To allow $\mathrm{pH}$ control (at $\mathrm{pH}$ 6.5), to maintain $\mathrm{pH}$ at its optimal value, a larger bioreactor (3 L working volume) was used and experiments were performed in the optimal conditions determined in batch mode using $125 \mathrm{~mL}$ glass bottles.

\subsection{Batch study in 3 L bioreactor with pH control}

The degradation profiles of glucose and ammonium with heat treated anaerobic sludge and that of the biomass concentration expressed by the Suspended solids (SS) are illustrated in Figure 3. Glucose was completely $(98.5 \%)$ consumed after $48 \mathrm{~h}$ of fermentation, with a maximum conversion efficiency of glucose to hydrogen (based on a theoretical yield of $4 \mathrm{~mol} \mathrm{H}_{2} \mathrm{~mol}^{-1}$ glucose consumed ) of $50.7 \%$ for heat-treated samples at a $\mathrm{pH}$ of 6.5 (Figure 3).

Concerning the ammonium curve, Figure 3 shows that ammonium assimilation yields increased with time to reach an optimal of $86.4 \%$ at $48 \mathrm{~h}$ which remained then approximately constant until the end of culture. Suspended solids showed a peak $\left(22.5 \mathrm{~g} \mathrm{~L}^{-1}\right)$ at $48 \mathrm{~h}$. Inhibition of growth and cessation of $\mathrm{NH}_{4}{ }^{+}$consumption after $48 \mathrm{~h}$ of fermentation s can be attributed to a carbon limitation, since glucose depletion (98.8\%) was observed after $48 \mathrm{~h}$ of culture. 


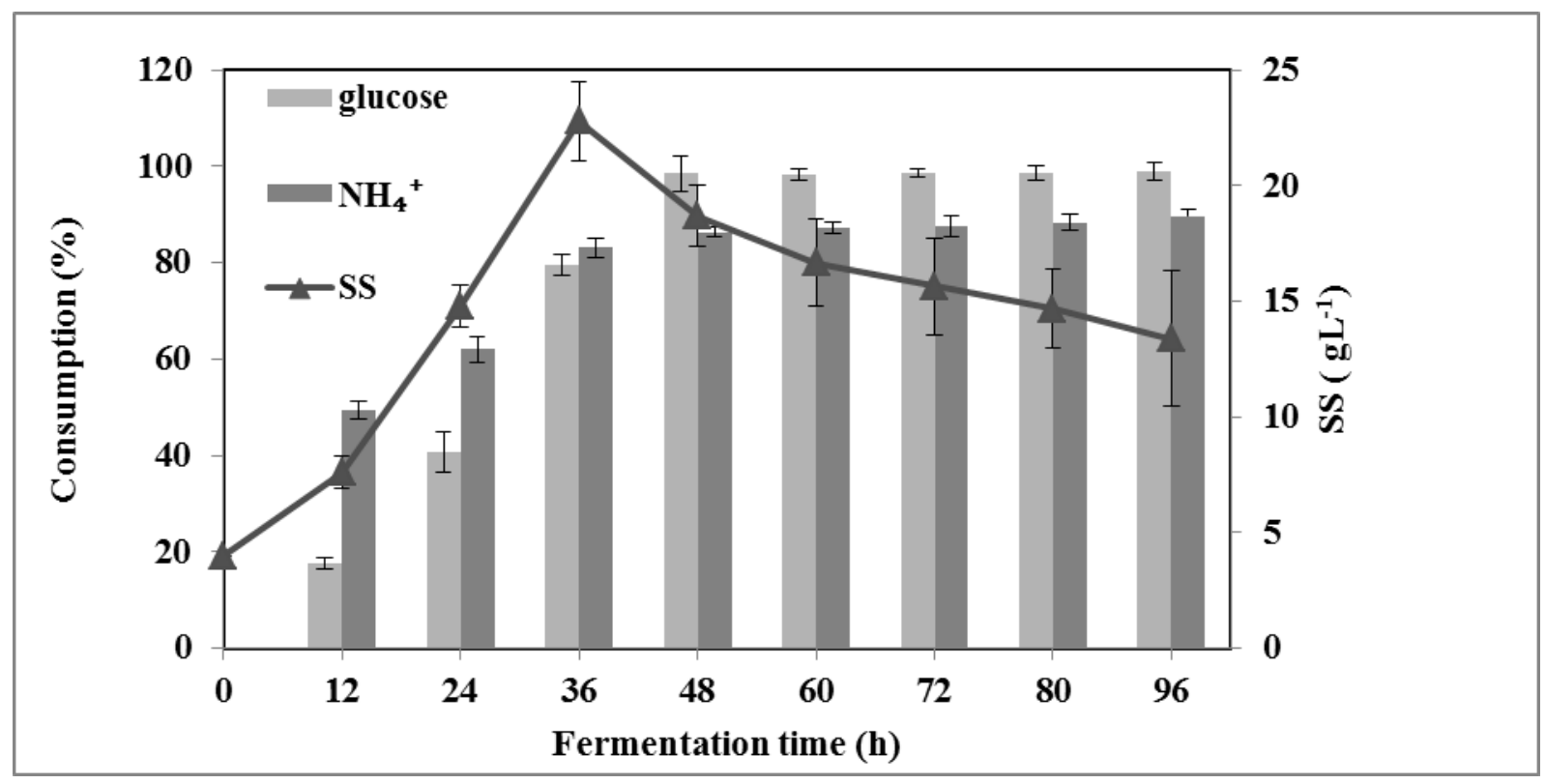

Figure 3: Time-courses of biomass growth, ammonium and glucose consumption during dark fermentation by heat treated sludge cultivated in a $3 \mathrm{~L}$ bioreactor with $\mathrm{pH}$ controlled at 6.5 and containing $25 \mathrm{~g} \mathrm{~L}^{-1}$ glucose. Errors are based on duplicate experiments.

$\mathrm{T}$ The $\mathrm{H}_{2}$ yield profiles (Figure 4) in the reactor headspace were in agreement with the microbial growth (Figure 3), since it increased until reaching a maximum value of $2.03 \mathrm{~mol} \mathrm{H}_{2} \mathrm{~mol}^{-1}$ glucose consumed after $48 \mathrm{~h}$ culture, followed by a decrease until $1.13 \mathrm{~mol} \mathrm{H}_{2} \mathrm{~mol}^{-1}$ glucose consumed after $60 \mathrm{~h}$ and remained then nearly constant until end of culture. Such a decrease was likely to be associated with the consumption of $\mathrm{H}_{2}$ from the headspace by homoacetogens (Clostridium aceticum) [18] and by hydrogenotrophic methanogens (archaebacteria) [23]. 


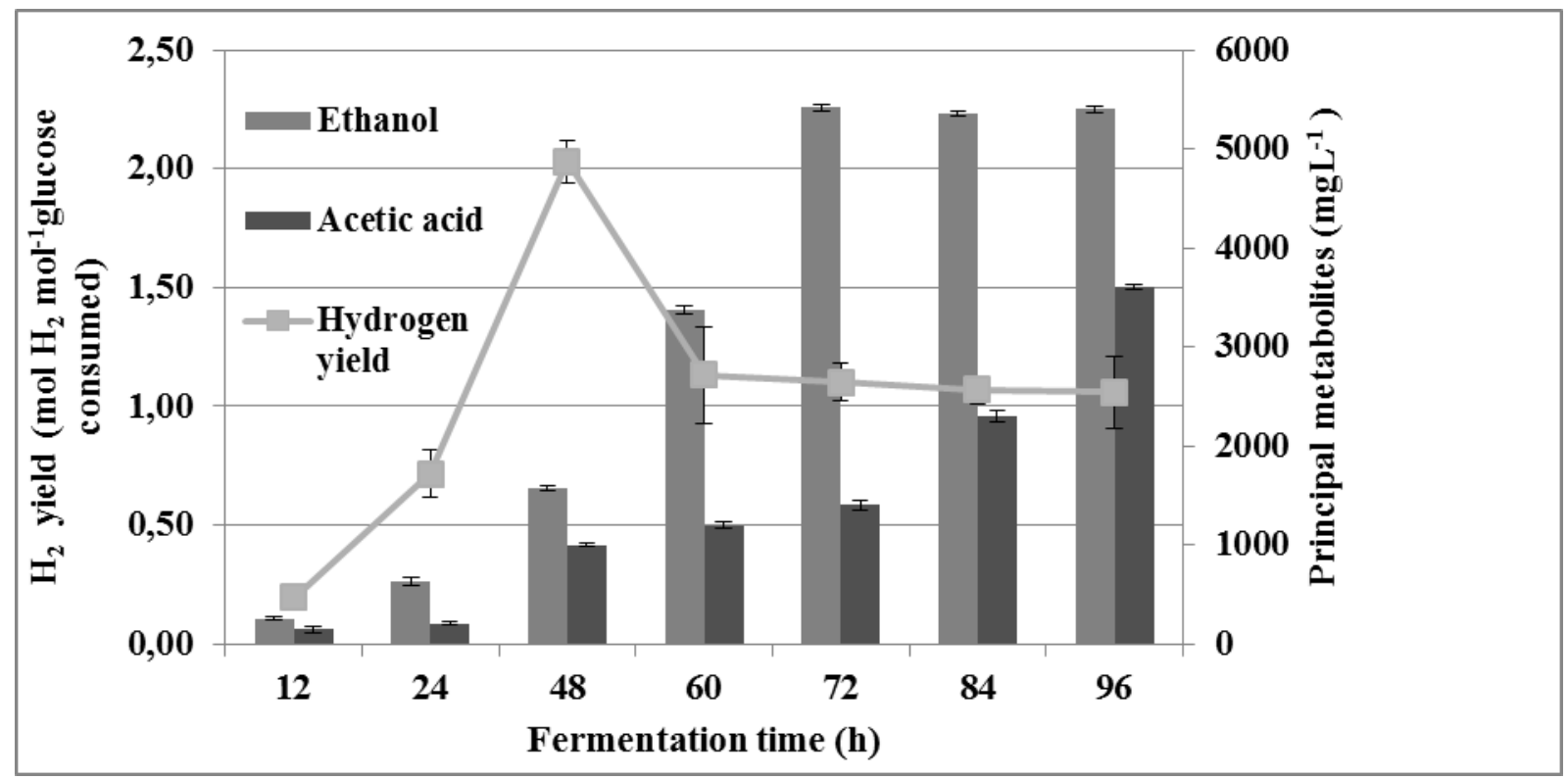

Figure 4: Time courses of the main metabolites and hydrogen production during dark fermentation by heat treated sludge cultivated in a $3 \mathrm{~L}$ bioreactor with $\mathrm{pH}$ controlled at 6.5 and containing $25 \mathrm{~g} \mathrm{~L}^{-}$ ${ }^{1}$ glucose. Errors are based on duplicate experiments.

However, no methanogenesis was observed throughout the experiment as no $\mathrm{CH}_{4}$ was detected in the samples. This Implies that $\mathrm{H}_{2}$ might be utilized by some other microorganisms, such as homoacetogens. Spore-forming clostridia, e.g, C. aceticum and C. thermoautrophicum, are known to produce acetate from $\mathrm{H}_{2}$ and $\mathrm{CO}_{2}$ via the following reaction [62].

\section{$2 \mathrm{HCO}_{3}^{-}+4 \mathrm{H}_{2}+\mathrm{H}^{+} \longrightarrow \mathrm{CH}_{3} \mathrm{COO}^{-}+4 \mathrm{H}_{2} \mathrm{O}$}

This fact was confirmed from analysis of the biogas and the culture medium (Figure 4).The produced gas contained only hydrogen and carbon dioxide, and both compounds increased with the progress of the fermentation until reaching a maximum of 0.115 and $0.009 \mathrm{~mol} \mathrm{~L}^{-1}$ after $48 \mathrm{~h}$ respectively (data no shown). The biogas was free of methane; showing that the heat treated method was effective to remove methanogenesis and to enrich $\mathrm{H}_{2}$-producing inoculum from mixed anaerobic sludge. Concerning, the culture medium, the main metabolites were acetic acid and ethanol, which increased with the progress of fermentation; after when glucose depletion, beyond 
$72 \mathrm{~h}$, the amount of ethanol remained nearly unchanged, while that of acetic acid continued to increased. This production of acetic acid and the loss of hydrogen from the headspace despite the absence of organic carbon source, glucose, was most likely due to homoacetogenesis.

Finaly, the $\mathrm{pH}$ control of the culture medium led to a significant increase in the hydrogen gas conversion efficiency via heat-treated anaerobic activated sludge, $2.02 \mathrm{~mol} \mathrm{H}_{2} \mathrm{~mol}^{-1}$ glucose consumed, versus $1.1 \mathrm{~mol} \mathrm{H}_{2} \mathrm{~mol}^{-1}$ glucose consumed obtained without $\mathrm{pH}$ control (Figure 1) and $0.35 \mathrm{~mol} \mathrm{H}_{2} \mathrm{~mol}^{-}$

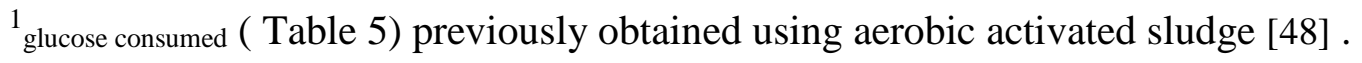

Table 5: Summary of the $\mathrm{H}_{2}$ production results obtained in $125 \mathrm{~mL}$ (without $\mathrm{pH}$ control) and $3 \mathrm{~L}$ batch reactors (with $\mathrm{pH}$ control). Error bars are based on duplicate experiments. (Incubation time $=48 \mathrm{~h}$, Ammonium solution generated electrochemistry $=8.6 \mathrm{~g} \mathrm{NH}_{4}^{+} . \mathrm{L}^{-1}$ )

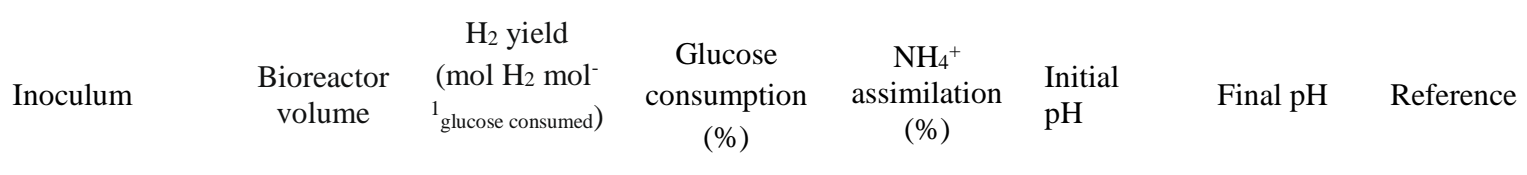

\begin{tabular}{|c|c|c|c|c|c|c|c|c|}
\hline $\begin{array}{c}\text { without } \\
\mathrm{pH} \\
\text { control }\end{array}$ & $\begin{array}{c}\text { heat-treated } \\
\text { aerobic } \\
\text { activated sludge }\end{array}$ & $125 \mathrm{~mL}$ & $0.35 \pm 0.01$ & $82 \pm 2.0$ & $97.0 \pm 3.5$ & $5.5 \pm 0.2$ & $3.5 \pm 0.1$ & $\begin{array}{l}\text { previous } \\
\text { study [48] }\end{array}$ \\
\hline $\begin{array}{c}\text { without } \\
\mathrm{pH} \\
\text { control }\end{array}$ & $\begin{array}{l}\text { heat-treated } \\
\text { anaerobic } \\
\text { sludge }\end{array}$ & $125 \mathrm{~mL}$ & $1.1 \pm 0,01$ & $85.1 \pm 1.5$ & $98.8 \pm 3.1$ & $6.5 \pm 0.1$ & $5.0 \pm 0.4$ & $\begin{array}{l}\text { This } \\
\text { study }\end{array}$ \\
\hline $\begin{array}{l}\text { With pH } \\
\text { control }\end{array}$ & $\begin{array}{l}\text { heat-treated } \\
\text { anaerobic } \\
\text { sludge }\end{array}$ & $3 \mathrm{~L}$ & $2.02 \pm 0.03$ & $98.5 \pm 2.2$ & $86.4 \pm 1.4$ & $6.5 \pm 0.15$ & $6.5 \pm 0.15$ & $\begin{array}{l}\text { This } \\
\text { study }\end{array}$ \\
\hline
\end{tabular}

The comparison of the $\mathrm{H}_{2}$ yield obtained in this study using anaerobic activated sludge to those of the literature performed in similar conditions shows higher yields, namely $2.02 \mathrm{~mol} \mathrm{H}_{2} \mathrm{~mol}^{-1}$ glucose consumed in this work versus $1.17 \mathrm{~mol} \mathrm{H}_{2} \mathrm{~mol}^{-1}$ glucose consumed [27] and 0,96 mol H $\mathrm{mol}^{-1}$ glucose consumed [23] or quite similar $2.00 \mathrm{~mol} \mathrm{H}_{2} \mathrm{~mol}^{-1}$ glucose consumed [63]. 


\section{Conclusions}

The results and findings of this study can be summarized as follows.Ammonium solutions resulting from nitrate electrochemical treatment can be substituted to the commercial products used as a nitrogen source to convert anaerobically glucose to $\mathrm{H}_{2}$ in dark fermentation process.

The control of the culture medium $\mathrm{pH}$ had a strong influence on dark fermentative hydrogen production efficiency. In the optimal conditions corresponding to $\mathrm{pH} 6.5$ and $25 \mathrm{~g} \mathrm{~L}^{-1}$ of initial glucose concentration and using heat treated anaerobic sludge, a hydrogen yield of $2.02 \mathrm{~mol}_{2}$ $\mathrm{mol}^{-1}$ glucose consumed was obtained by controlling the $\mathrm{pH}$, versus $1.1 \mathrm{~mol} \mathrm{H}_{2} \mathrm{~mol}^{-1}$ glucose consumed recorded without $\mathrm{pH}$ control; it was also higher than the yield obtained in our previous study [48] with aerobic activated sludge $\left(0.35 \mathrm{~mol} \mathrm{H}_{2} \mathrm{~mol}^{-1}\right.$ glucose consumed $)$.

A complete assimilation of the obtained $\mathrm{NH}_{4}^{+}\left(0.86 \mathrm{~g} \mathrm{~L}^{-1} \mathrm{NH}_{4}{ }^{+}\right)$and the added glucose $(25 \mathrm{~g}$ $\mathrm{L}^{-1}$ ) was achieved in both cases (with and without $\mathrm{pH}$ control). It is indeed a challenge to implement the process on an industrial scale but investigations at a pilot scale seems to be necessary prior to such implementation, especially considering that researches dealing with dark fermentation on a pilot scale are scarce, as well as the lack of studies on an industrial scale.

\section{Acknowledgements}

The authors gratefully acknowledge the financial support of the Lebanese Social Association Azm and Saadeh and Campus France.

\section{References}

[1] Show K-Y, Lee D-J, Chang J-S. Bioreactor and process design for biohydrogen production. Spec Issue Biofuels-III Biohydrogen 2011;102:8524-33. doi:10.1016/j.biortech.2011.04.055.

[2] Abbasi T, Abbasi SA. "Renewable"hydrogen: prospects and challenges. Renew Sustain Energy Rev 2011;15:3034-40. 
[3] Hallenbeck PC, Abo-Hashesh M, Ghosh D. Strategies for improving biological hydrogen production. Bioresour Technol 2012;110:1-9. doi:10.1016/j.biortech.2012.01.103.

[4] Hallenbeck PC. Fermentative hydrogen production: principles, progress, and prognosis. Int J Hydrog Energy 2009;34:7379-89.

[5] Momirlan M, Veziroğlu T. Recent directions of world hydrogen production. Renew Sustain Energy Rev 1999;3:219-31.

[6] Rittmann S, Herwig C. A comprehensive and quantitative review of dark fermentative biohydrogen production. Microb Cell Factories 2012;11:115. doi:10.1186/1475-2859-11-115.

[7] Wang A-J, Cao G-L, Liu W-Z. Biohydrogen Production from Anaerobic Fermentation. Biotechnol. China III Biofuels Bioenergy, Springer; 2012, p. 143-63.

[8] Ghimire A, Frunzo L, Pontoni L, d'Antonio G, Lens PN, Esposito G, et al. Dark fermentation of complex waste biomass for biohydrogen production by pretreated thermophilic anaerobic digestate. J Environ Manage 2015;152:43-8.

[9] Hawkes FR, Hussy I, Kyazze G, Dinsdale R, Hawkes DL. Continuous dark fermentative hydrogen production by mesophilic microflora: principles and progress. Int J Hydrog Energy $2007 ; 32: 172-84$.

[10] Logan BE, Oh S-E, Kim IS, Van Ginkel S. Biological Hydrogen Production Measured in Batch Anaerobic Respirometers. Environ Sci Technol 2002;36:2530-5. doi:10.1021/es015783i.

[11] Rivera I, Buitrón G, Bakonyi P, Nemestóthy N, Bélafi-Bakó K. Hydrogen production in a microbial electrolysis cell fed with a dark fermentation effluent. J Appl Electrochem 2015;45:1223-9.

[12] Jung K-W, Kim D-H, Kim S-H, Shin H-S. Bioreactor design for continuous dark fermentative hydrogen production. Spec Issue Biofuels-III Biohydrogen 2011;102:8612-20. doi:10.1016/j.biortech.2011.03.056. 
[13] Bakonyi P, Nemestóthy N, Simon V, Bélafi-Bakó K. Review on the start-up experiences of continuous fermentative hydrogen producing bioreactors. Renew Sustain Energy Rev 2014;40:806-13. doi:10.1016/j.rser.2014.08.014.

[14] Kumar G, Bakonyi P, Periyasamy S, Kim SH, Nemestóthy N, Bélafi-Bakó K. Lignocellulose biohydrogen: Practical challenges and recent progress. Renew Sustain Energy Rev $2015 ; 44: 728-37$.

[15] Arooj MF, Han S-K, Kim S-H, Kim D-H, Shin H-S. Sludge characteristics in anaerobic SBR system producing hydrogen gas. Water Res 2007;41:1177-84. doi:10.1016/j.watres.2006.11.052.

[16] Rafieenia R. A metabolic model for investigation of the fermentative hydrogen production by Clostridium butyricum w5 grown on xylose. Asian J Exp Biol Sci 2013;4:472-5.

[17] Fang HH, Liu H. Effect of $\mathrm{pH}$ on hydrogen production from glucose by a mixed culture. Bioresour Technol 2002;82:87-93.

[18] Karadag D, Mäkinen AE, Efimova E, Puhakka JA. Thermophilic biohydrogen production by an anaerobic heat treated-hot spring culture. Bioresour Technol 2009;100:5790-5.

[19] Morsy FM. CO 2-free biohydrogen production by mixed dark and photofermentation bacteria from sorghum starch using a modified simple purification and collection system. Energy 2015;87:594-604.

[20] Niu K, Zhang X, Tan W-S, Zhu M-L. Characteristics of fermentative hydrogen production with Klebsiella pneumoniae ECU-15 isolated from anaerobic sewage sludge. Int J Hydrog Energy 2010;35:71-80. doi:10.1016/j.ijhydene.2009.10.071.

[21] Wang B, Yin YN, Cheng R, Zhang Q, Wang L, Yang Y, et al. Effect of Sulfate Concentration on Biohydrogen Production by Enriched Anaerobic Sludge. Adv Mater Res 2014;884885:433-6. doi:10.4028/www.scientific.net/AMR.884-885.433. 
[22] Xiao Y, Zhang X, Zhu M, Tan W. Effect of the culture media optimization, $\mathrm{pH}$ and temperature on the biohydrogen production and the hydrogenase activities by Klebsiella pneumoniae ECU-15. Bioresour Technol 2013;137:9-17. doi:10.1016/j.biortech.2013.03.109.

[23] Oh S-E, Van Ginkel S, Logan BE. The relative effectiveness of $\mathrm{pH}$ control and heat treatment for enhancing biohydrogen gas production. Environ Sci Technol 2003;37:5186-90.

[24] Lay J-J. Modeling and optimization of anaerobic digested sludge converting starch to hydrogen. Biotechnol Bioeng 2000;68:269-78. doi:10.1002/(SICI)10970290(20000505)68:3<269::AID-BIT5>3.0.CO;2-T.

[25] Zhang Z-P, Adav SS, Show K-Y, Tay J-H, Liang DT, Lee D-J, et al. Characteristics of rapidly formed hydrogen-producing granules and biofilms. Biotechnol Bioeng 2008;101:926-36. doi:10.1002/bit.21956.

[26] Kim IS, Hwang MH, Jang NJ, Hyun SH, Lee ST. Effect of low pH on the activity of hydrogen utilizing methanogen in bio-hydrogen process. Int J Hydrog Energy 2004;29:1133-40. doi:10.1016/j.ijhydene.2003.08.017.

[27] Salerno MB, Park W, Zuo Y, Logan BE. Inhibition of biohydrogen production by ammonia. Water Res 2006;40:1167-72.

[28] Wang X, Jin B, Mulcahy D. Impact of carbon and nitrogen sources on hydrogen production by a newly isolated Clostridium butyricum W5. Int J Hydrog Energy 2008;33:4998-5005. doi:10.1016/j.ijhydene.2008.07.078.

[29] Bisaillon A, Turcot J, Hallenbeck PC. The effect of nutrient limitation on hydrogen production by batch cultures of Escherichia coli. IHEC 2005 COST Action 841 Final Meet 2006;31:1504-8. doi:10.1016/j.ijhydene.2006.06.016.

[30] Reyter D, Belanger D, Roue L. Study of the electroreduction of nitrate on copper in alkaline solution. Electrochimica Acta 2008;53:5977-84. 
[31] Carpenter SR, Caraco NF, Correll DL, Howarth RW, Sharpley AN, Smith VH. Nonpoint pollution of surface waters with phosphorus and nitrogen. Ecol Appl 1998;8:559-68.

[32] Cheng H, Scott K, Christensen PA. Paired electrolysis in a solid polymer electrolyte reactorSimultaneously reduction of nitrate and oxidation of ammonia. Chem Eng J 2005;108:257-68.

[33] Katsounaros I, Ipsakis D, Polatides C, Kyriacou G. Efficient electrochemical reduction of nitrate to nitrogen on tin cathode at very high cathodic potentials. Electrochimica Acta 2006;52:1329-38.

[34] Reyter D, Bélanger D, Roué L. Optimization of the cathode material for nitrate removal by a paired electrolysis process. J Hazard Mater 2011;192:507-13. doi:10.1016/j.jhazmat.2011.05.054.

[35] Reyter D, Bélanger D, Roué L. Nitrate removal by a paired electrolysis on copper and Ti/IrO2 coupled electrodes - Influence of the anode/cathode surface area ratio. Water Res 2010;44:1918-26. doi:10.1016/j.watres.2009.11.037.

[36] Dortsiou M, Kyriacou G. Electrochemical reduction of nitrate on bismuth cathodes. J Electroanal Chem 2009;630:69-74. doi:10.1016/j.jelechem.2009.02.019.

[37] Doan HD, Wu J, Mitzakov R. Combined electrochemical and biological treatment of industrial wastewater using porous electrodes. J Chem Technol Biotechnol 2006;81:1398-408.

[38] Fontmorin J-M, Fourcade F, Geneste F, Soutrel I, Floner D, Amrane A. Direct electrochemical oxidation of a pesticide, 2,4-dichlorophenoxyacetic acid, at the surface of a graphite felt electrode: Biodegradability improvement. Comptes Rendus Chim 2015;18:32-8. doi:10.1016/j.crci.2014.05.004.

[39] Saidi I, Soutrel I, Floner D, Fourcade F, Bellakhal N, Amrane A, et al. Indirect electroreduction as pretreatment to enhance biodegradability of metronidazole. J Hazard Mater 2014;278:172-9. doi:10.1016/j.jhazmat.2014.06.003. 
[40] Bouzek K, Paidar M, Sadílková A, Bergmann H. Electrochemical reduction of nitrate in weakly alkaline solutions. J Appl Electrochem 2001;31:1185-93. doi:10.1023/A:1012755222981.

[41] Chu C-Y, Tung L, Lin C-Y. Effect of substrate concentration and $\mathrm{pH}$ on biohydrogen production kinetics from food industry wastewater by mixed culture. Int J Hydrog Energy 2013;38:15849-55. doi:10.1016/j.ijhydene.2013.07.088.

[42] Liu G, Shen J. Effects of culture and medium conditions on hydrogen production from starch using anaerobic bacteria. J Biosci Bioeng 2004;98:251-6.

[43] Morimoto M, Atsuko M, Atif AAY, Ngan MA, Fakhru'l-Razi A, Iyuke SE, et al. Biological production of hydrogen from glucose by natural anaerobic microflora. Int J Hydrog Energy 2004;29:709-13.

[44] Chong M-L, Rahim RA, Shirai Y, Hassan MA. Biohydrogen production by Clostridium butyricum EB6 from palm oil mill effluent. Int J Hydrog Energy 2009;34:764-71. doi:10.1016/j.ijhydene.2008.10.095.

[45] Yokoi H, Saitsu A, Uchida H, Hirose J, Hayashi S, Takasaki Y. Microbial hydrogen production from sweet potato starch residue. J Biosci Bioeng 2001;91:58-63. doi:10.1016/S1389-1723(01)80112-2.

[46] Yokoi H, Ohkawara T, Hirose J, Hayashi S, Takasaki Y. Characteristics of hydrogen production by aciduric Enterobacter aerogenes strain HO-39. J Ferment Bioeng 1995;80:5714. doi:10.1016/0922-338X(96)87733-6.

[47] Cheng H-H, Whang L-M, Chung M-C, Chan K-C. Biological hydrogen and methane production from bagasse bioethanol fermentation residues using a two-stage bioprocess. Bioresour Technol n.d. doi:10.1016/j.biortech.2015.12.084. 
[48] Abdallah R, Amrane A, Djelal H, Taha S, Fourcade F, Labasque T, et al. Energetic valorization of ammonium resulting from nitrate electrochemical reduction-Feasibility of biohydrogen production. Biochem Eng J 2015;94:145-52. doi:10.1016/j.bej.2014.11.019.

[49] Wang J, Wan W. Comparison of different pretreatment methods for enriching hydrogenproducing bacteria from digested sludge. Int J Hydrog Energy 2008;33:2934-41.

[50] Lee M-J, Zhang S, Cho Y-B, Park J-E, Chang K-H, Hwang S-J. Effects of nitrate concentration on biohydrogen production and substrate utilization in dark-fermentation. $\mathbf{J}$ Mater Cycles Waste Manag 2015;17:27-32.

[51] van der Hoek JP, van der Ven PJ, Klapwijk A. Combined ion exchange/biological denitrification for nitrate removal from ground water under different process conditions. Water Res 1988;22:679-84.

[52] Kim J, Benjamin MM. Modeling a novel ion exchange process for arsenic and nitrate removal. Water Res 2004;38:2053-62. doi:10.1016/j.watres.2004.01.012.

[53] Abdallah R, Geneste F, Labasque T, Djelal H, Fourcade F, Amrane A, et al. Selective and quantitative nitrate electroreduction to ammonium using a porous copper electrode in an electrochemical flow cell. J Electroanal Chem 2014;727:148-53. doi:10.1016/j.jelechem.2014.06.016.

[54] Fang H, Zhang T, Liu H. Microbial diversity of a mesophilic hydrogen-producing sludge. Appl Microbiol Biotechnol 2002;58:112-8. doi:10.1007/s00253-001-0865-8.

[55] Zhang Y, Shen J. Effect of temperature and iron concentration on the growth and hydrogen production of mixed bacteria. Int J Hydrog Energy 2006;31:441-6.

[56] Eaton AD, Franson MAH. Standard methods for the examination of water \& wastewater. Amer Public Health Assn; 2005.

[57] Frear DS, Burrell RC. Spectrophotometric method for determining hydroxylamine reductase activity in higher plants. Anal Chem 1955;27:1664-5. 
[58] Greenberg AE, Clesceri LS, Eaton AD. Standard Methods for the Examination of Water and Wastewater, American Public Health Association, Washington, DC 1992.

[59] Tang J, Yuan Y, Guo W-Q, Ren N-Q. Inhibitory effects of acetate and ethanol on biohydrogen production of Ethanoligenens harbinese B49. 11th China Hydrog Energy Conf 2012;37:741-7. doi:10.1016/j.ijhydene.2011.04.067.

[60] Han W, Liu DN, Shi YW, Tang JH, Li YF, Ren NQ. Biohydrogen production from food waste hydrolysate using continuous mixed immobilized sludge reactors. Bioresour Technol 2015;180:54-8.

[61] Guo XM, Trably E, Latrille E, Carrère H, Steyer J-P. Hydrogen production from agricultural waste by dark fermentation: A review. Int J Hydrog Energy 2010;35:10660-73. doi:10.1016/j.ijhydene.2010.03.008.

[62] Minton NP, Clarke DJ. Clostridia-Biotechnology Handbook, Vol. 3. Plenum Press., New York; 1989.

[63] Mu Y, Yu H-Q, Wang G. Evaluation of three methods for enriching H2-producing cultures from anaerobic sludge. Enzyme Microb Technol 2007;40:947-53. doi:10.1016/j.enzmictec.2006.07.033. 